проект навчально-виховного процесу, що визначає структуру і зміст діяльності самого слухача (учня, студента); концептуальність (кожна педагогічна технологія повинна спиратися на певну наукову концепцію, яка передбачатиме філософське, психологічне, дидактичне та соціально-педагогічне обгрунтування освітніх цілей на основі системного підходу); керованість; ефективність (сучасні педагогічні технології існують в умовах конкуренції і мають бути ефективними за результатами та оптимальними затратами, а також гарантувати досягнення певного стандарту навчання); репродуктивність, що припускає можливість використання (повторення, відновлення) педагогічної технології в інших однотипних освітніх установах, іншими суб'єктами.

\title{
Література
}

1. Беспалько В. Слагаемые педагогической технологии / В. Беспалько. - Москва, 1989. - 139 с. 2. Використання педагогічних технологій у практиці роботи сучасної школи: [зб. наук. праць за матеріалами міжнар. наук.-практ. інтернет-конф., 15-17 лют. 2012 р.] / МОНмолодьспорту України, ДВНЗ «Переяслав-Хмельницький держ. пед. ун-т імені Григорія Сковороди»[та ін.]; наук. ред. Н. П. Оніщенко. - Переяслав-Хмельницький: «Вид-во КСВ», 2012. - 320 с. 3. Енциклопедія освіти / Акад. пед. наук України; головний ред. В. Г. Кремень. - Київ : Юрінком Інтер, 2008. - 1040 с. 4. Зязюн І. А. Філософія педагогічної дії: [монографія] / І. А. Зязюн. Черкаси : Вид. від. ЧНУ імені Богдана Хмельницького, 2008. - 608 с. 5. Концептуальні підходи до розвитку багаторівневої педагогічної освіти в Україні (Проект)/ уклад. : Андрущенко В. П., Зязюн І. А. - Київ, 2011. - 16 с. 6. Лернер И. Внимание: технологии обучения // Советская педагогика. - 1990. - № 3. - С. 91-98. 7. Наволокова Н. П. Технологія розвитку критичного мислення // Педагогічна майстерня. - № 4 (40) квітень 2014 р. - С. 2831. 8. Селевко Г. К. Альтернативные педагогические технологии / Герман Константинович Селевко. - Москва : НИИ школьных технологий, 2005. - 224 с. - (Серия «Энциклопедия образовательных технологий»). 9. Суртаева Н. Н. Инновационные процессы в социализации личности / Н. Н. Суртаева / Проблемы педагогической инноватики в профессиональной школе: [материалы 2-й межрегиональной межотраслевой научно-практической конференции с участием ближнего и дальнего зарубежья]. Ч. 1.- Санкт-Петербург, 2001.- С. 5-7. 10. Шапран О. І. Сучасні педагогічні технології у професійній підготовці вчителів: [навч. посіб.] / за ред. О. І. Шапран. - Переяслав-Хмельницький: «Вид-во КСВ», 2012. - 279 с.

УДК 378.016:811.161.2

Олександра Пальчикова

\section{ПРОБЛЕМИ ПРОГРАМНО-МЕТОДИЧНОГО ЗАБЕЗПЕЧЕННЯ НАВЧАННЯ УКРАЇНСЬКОЇ МОВИ ЯК ІНОЗЕМНОЇ}

Пальчикова О. О. Проблеми програмно-методичного забезпечення навчання української мови як іноземної.

У статті проаналізовано проблеми програмно-методичного забезпечення навчання української мови на підготовчому відділенні. Розглянуто базові навчальні плани та програми, затверджені та рекомендовані Міністерством освіти і науки, молоді та спорту України. Визначено основну мету й завдання у процесі укладання навчальних програм 3 української мови як іноземної.

Ключові слова: соціокультурне оточення, країнознавчий складник, соціокультурна царина, лексичний мінімум, соціокультурна компетентність. 
Пальчикова А. А. Проблемы программно-методического обеспечения обучения украинскому языку как иностранному.

В статье проанализированы проблемы программно-методического обеспечения обучения украинскому языку на подготовительном отделении. Рассмотрены базовые учебные планы и программы, утвержденные и рекомендованные Министерством образования и науки, молодежи и спорта Украины. Определена основная цель и задания в процессе составления учебных программ по украинскому языку как иностранному.

Ключевые слова: социокультурное окружение, страноведческая составляющая, социокультурная сфера, лексический минимум, социокультурная компетентность.

Palchickova O. O. The problems of methodical support in teaching Ukrainian as a foreign language.

The problems of methodical support in teaching Ukrainian as a foreign language at the preparatory department are analyzed. The basic curricula and syllabi recommended by the Ministry of Education and Science, Youth and Sports of Ukraine are considered. The author defines the key goal and tasks in the process of drawing up curricula and syllabi for Ukrainian as a foreign language.

Key words: socio-cultural environment, cross-cultural constituent, socio-cultural area, lexical minimum, socio-cultural competency.

Важливим компонентом державної Концепції мовної освіти $є$ Концепція мовної підготовки іноземців, підгрунтям якої вважають основні положення Конституції України, закон України «Про освіту», Державну національну програму «Освіта: Україна XXI століття», Європейську хартію регіональних мов або меншин, Загальноєвропейські Рекомендації з мовної освіти.

За словами розробників концепції мовної підготовки іноземців у ВНЗ (Н. Ушакова, В. Дубичинський, О. Тростинська), мова розглядається нині не лише як навчальний предмет, а й засіб усебічного розвитку особистості та інструмент, необхідний для отримання іноземцями професійних якостей [5, с. 139]. Відтак мова навчання набуває статусу мови соціокультурного оточення та $€$ обов'язковим атрибутом у процесі формування вмінь $\mathrm{i}$ навичок крос-культурної комунікації. Звідси виходить, що концепція мовної підготовки стає важливим компонентом підвищення результативності навчання іноземних студентів. У свою чергу, основами ефективного впровадження мовної підготовки в освітній процес можна вважати навчальні плани та програми з української мови як іноземної, затверджені та рекомендовані Міністерством освіти і науки, молоді та спорту України.

Mета статmі- проаналізувати програмно-методичне забезпечення у процесі навчання української мови як іноземної.

Згідно з базовими навчальними планами, рекомендованими Навчально-методичною комісією з пропедевтичної підготовки іноземних громадян Міністерства освіти і науки України, вступний курс української мови для всіх спеціальностей складає чотири тижні, упродовж яких студенти ознайомлюються із фонетичним, лексичним, граматичним матеріалом, необхідним для елементарного спілкування в межах навчального закладу та поза ним; освоюють наукову лексику, якою послуговуватимуться на заняттях із профільних дисциплін. Наприкінці першого і другого семестрів студенти складають залік та іспит. На четвертому тижні вводиться поступове вивчення предметів, профільних для певної спеціальності, зокрема математики, креслення, основ інформатики й обчислювальної 
техніки, фізики, хімії, країнознавства тощо.

Звертаючи увагу на співвідношення в навчальних планах підготовчого відділення профільних і непрофільних дисциплін для іноземних студентів, більша частина годин припадає на вивчення останніх, а саме - української мови, де річний обсяг годин у межах спеціальностей фізика, хімія, а також інженерно-технічних, інженерно-економічних складає 1080 годин, із них 720 годин відведено на аудиторні заняття, 360 - на самостійне опрацювання.

Загальна кількість годин, необхідних для навчання української мови на економічних спеціальностях, дорівнює 1116, де 744 години - аудиторні заняття, 360 - самостійна робота. На спеціальностях математика, механіка українська мова вивчається в обсязі 1083 години на рік, при цьому 722 години виділено на аудиторні заняття, 361 - на самостійне опрацювання.

Щодо гуманітарних спеціальностей гуманітарні та психологія, констатуємо такий розподіл годин: разом - 1257 та 1200, аудиторних занять - 838 і 800, самостійна підготовка 419 та 400 відповідно.

Отже, виходячи зі змісту навчальних планів видно, що кількість годин, відведених на навчання української мови, $є$ достатньою для оволодіння іноземними студентами знаннями, необхідним рівнем умінь та навичок для засвоєння матеріалу на початкових заняттях із профільних загальноосвітніх дисциплін [2].

Одним із важелів регулювання процесу оволодіння іноземними студентами українською мовою є програми. «Програма з української мови для студентів-іноземців підготовчих факультетів України» рекомендована науково-методичною комісією 3 довузівської підготовки іноземних громадян Міністерства освіти і науки України (від 21 лютого 2002 року, протокол № 4) [3]. Її зміст поділено на три рівні, яким відповідають елементарний курс, мовний матеріал першого і другого семестрів. Кількість навчальних годин, відведених на означений рівень, складає 150; засвоєних активних лексичних значеннєвих одиниць - 400-500, пасивних - 50. Обсяг навчального матеріалу на другому рівні розрахований на 300 навчальних годин, із яких кількість засвоєних активних лексичних значеннєвих одиниць дорівнює 850-890, пасивних - 100.

Кількість годин, відведених на ознайомлення з мовним матеріалом третього рівня, становить 270 навчальних годин. Кількість засвоєних активних лексичних значеннєвих одиниць - 750-800, пасивних - 100-150.

У межах кожного рівня розподіл матеріалу відбувається за мовним та країнознавчим блоками. У першому розглянуто характерні риси фонетичної, лексичної, морфологічної, синтаксичної систем української мови. Так, на елементарному курсі 3-поміж основних розділів фонетичного сектора автори програми виокремлюють: практичну фонетику (ознайомлення з роботою органів мовлення, особливостями вимови звуків української мови), фонетичне членування мовного потоку, голосні звуки сучасної літературної української мови, артикуляційно-акустичну класифікацію приголосних звуків, орфоепію (вимова голосних і приголосних звуків), графіку й орфографію (вивчення характерних рис українського алфавіту).

На другому і третьому етапах увагу приділено переважно приголосним звукам, а саме: спрощенню в групах приголосних, подовженню та чергуванню останніх у визначених групах слів. У розділі «Орфоепія» розглянуто уподібнювальну палаталізацію передньоязикових приголосних та вимову дзвінко-дзвінких, дзвінко-глухих, глухо-глухих, глухо-дзвінких звукосполучень; здійснено огляд чергування фонем.

Лексичний мінімум першого рівня представлений темами: «Слово як одиниця мови», 
«Синоніми», «Антоніми». На другому щаблі відбувається більш поглиблене вивчення лексичного матеріалу, об’єднаного в блоки: «Багатозначність слів», «Метонімія», «Лексичні синоніми», «Антоніми», «Омоніми». У контексті третього рівня лексичний мовний матеріал характеризується емоційною насиченістю, що відображено в темах: «Метаморфоза», «Синекдоха», «Пароніми», «Власне українські слова», «Запозичення з інших мов», «Активна та пасивна лексика», «Професійна і діалектна лексика в сучасній українській мові», «Фразеологізми».

Матеріал морфологічного мінімуму першого та другого рівнів представлений самостійними частинами мови (іменник, прикметник, числівник, займенник, дієслово, прислівник) та службовими (прийменник, сполучник, частка, вигук); на третьому рівні до вищенаведених тем додають такі: «Морфемна структура слова», «Словотвір», «Дієприкметник», «Дієприслівник».

Синтаксичні структури елементарного курсу в межах речення презентовано такими темами: особові дієслова у формах теперішнього та минулого часу, дієслово «бути», хочу + інфінітив; питальна форма речень (загальні, спеціальні питання); дієслова доконаного / недоконаного виду. У контексті другого рівня вивчають обставинні прислівники часу; конструкції з модальними дієсловами: треба, потрібен, можна; вживання особових закінчень дієслів бути + інфінітив, дієслівних словосполучень у родовому, давальному, знахідному, орудному відмінках. На останньому етапі підготовчого відділення ключовим матеріалом синтаксичних конструкцій стає: іменний складений присудок, простий дієслівний присудок, виражений дієсловом умовного та наказового способу, інфінітивом; різні види особових і безособових, складносурядних і складнопідрядних речень, речень, ускладнених вставними і вставленими конструкціями.

Окрім мовного, окреслена програма характеризується також наявністю країнознавчого складника, що є основою синтаксичних структур та в якому віддзеркалено історію українського народу, життєвий устрій, презентовано відомості про символи, культурне надбання, ментальність. Відповідно, основними уміннями 3 чотирьох видів діяльності під час формування соціокультурної компетентності випускників підготовчого відділення є: точно зрозуміти, передати загальний зміст прочитаного та деталей, окремих положень; узяти участь у діалозі та побудувати власне висловлювання на країнознавчу тему; записати детальний конспект тексту з курсу «Країнознавство» чи укласти власне письмове висловлювання [3].

У 2008 році кафедра гуманітарних дисциплін Міжрегіональної академії управління персоналом м. Києва розробила навчальну програму 3 дисципліни «Українська мова» (довузівська підготовка). Головною метою програми розробники вважають комунікативну оволодіння українською мовою на рівні, достатньому для практичного застосування знань, умінь і навичок у визначених царинах професійного, ділового, побутового і культурного спілкування. Задля досягнення окресленої мети автори виокремлюють низку завдань:

- сформувати вміння сприйняття наукового стилю мовлення для майбутнього розуміння та відтворення навчальної інформації;

- розвивати навички повтору інформації з текстів і лекцій, ставити запитання та давати на них відповідь; брати участь у бесіді, будувати логічно завершене висловлювання, обираючи при цьому необхідні мовні засоби;

- забезпечити студентів знаннями про складання простого, складного і тезового плану, конспектування матеріалу, конструювання власного мікротексту на основі плану чи 
додаткових опор [1].

Програма містить п’ять модулів: три вивчаються в першому і два в другому семестрі. У першому змістовому модулі розміщено фонетико-граматичний курс, де подано класифікацію голосних і приголосних звуків української мови, вказана артикуляційноакустична класифікація останніх. 3-поміж частин мови, які вводяться в навчання, є: іменник, прикметник, займенник, числівник.

Другий змістовий модуль сфокусований на поглибленому вивченні самостійних i службових частин мови, зокрема надано інформацію про дієвідміни дієслова, категорію виду, перехідності, особи, часу, способу. У межах теми «Прислівник» запропоновано вивчення граматичних ознак названої частини мови.

У третьому змістовому модулі розкрито структурні класи дієслів, акцентовано на додаткових відтінках значень дієслівних форм недоконаного та доконаного виду. Деталізовано інформацію про службові частини мови: «Прийменник», «Сполучник», «Частка», «Вигук»; зокрема розкрито такі аспекти: вживання прийменників 3 формами іменників; сурядні єднальні та сурядні зіставно-протиставні сполучники, підрядні 3’єднувальні та підрядні обставинні сполучники часу, мети, умови, допустовості, порівняння, причини, наслідку; вигуки, що виражають емоції: страх, невдоволення, іронію [1].

Ключовими питаннями, що виносяться на розгляд у другому семестрі першого змістового модуля, $\epsilon$ лексика та словотвір. Основними темами для вивчення $\epsilon$ «Багатозначність слів», «Запозичення 3 інших слов'янських і неслов'янських мов», «Професійна та діалектна лексика», «Застарілі слова», «Неологізми», «Стійкі словосполучення».

Зміст другого змістового модуля сконцентровано на темі: «Поняття про речення». Задля цього пріоритетними для вивчення в зазначеному блоці автори вважають відомості про синтаксичні функції іменника та дієслова (складений підмет, виражений іменником, дієслівний простий присудок, виражений дієсловом умовного способу та інфінітивом; дієслівний складений присудок, виражений сполученням інфінітива 3 предикативними прикметниками та той, що виражений сполученням інфінітива 3 особливими формами дієслів із фазовим значенням; модальним значенням; дієслівний складений присудок, виражений сполученням інфінітива з усталеними сполуками); види речень (означеноособові, узагальнено-особові, безособові, складносурядні та складнопідрядні) [1].

Аналіз вищезазначеної програми дає підстави стверджувати про перевагу в останній мовного компонента над мовленнєвим: більшість інформації стосується фонетикограматичного та лексичного блоку, натомість соціокультурному, на наш погляд, приділено недостатньо уваги. У програмі присутня лексика, що відображає реалії суспільнополітичного життя (текст «МАУП», «Мій підготовчий факультет»), праці (тексти: «Вибір професії», «Наш художник»), проте явно бракує етнографічної лексики, що відбиває реалії духовної культури та мистецтва (представлена кількома текстами: «Маленький екскурсовод», «Територія, населення та національний склад України», «Дмитро Гнатюк», «Роксолана», «Т. Г. Шевченко»).

Кафедра української та російської мов як іноземних Харківської національної академії міського господарства (протокол № 6 від 18.02.2011) представила програму з української мови для студентів-іноземців, які навчаються на підготовчих факультетах (відділеннях) ВНЗ. Згідно з навчальним планом підготовчих факультетів для студентів-іноземців, обсяг годин, відведений на вивчення української мови в межах аудиторних занять, дорівнює 722. Відповідно до окресленої програми комунікативна мета навчання визнається головною і 
спрямована на розширення лексичного мінімуму суб'єктів навчання, розвиток усного й писемного, монологічного та діалогічного мовлення; підвищення рівня володіння вміннями й навичками аудіювання, говоріння, читання та письма в науково-навчальній i соціокультурній сферах комунікації. Відтак, до основних завдань розробники програми відносять:

1) надати знання іноземцям про особливості вживання різноманітних засобів української мови через практичне використання ключових мовних і мовленнєвих понять, формулювань, правил;

2) гарантувати оволодіння нормами української літературної мови;

3) сформувати країнознавчу компетенцію.

Виконання останньої вимоги передбачено в межах ситуативно-тематичного мінімуму соціокультурної сфери спілкування, що залучає обговорення тем, актуальних для сучасного середньостатистичного громадянина України та пов'язаних із повсякденним життям народу i глобальними проблемами сучасності. 3-поміж основних тем, на які програмою виділено 120 годин, автори виокремлюють: «Факультет», «Робочий день», «Наш гуртожиток», «Обід», «Знайомство», «Бібліотека», «Моя родина», «Познайомтеся, Харків», «Мій вихідний день», «Дружня допомога», «Супермаркет», «У гостях», «Прогулянка містом», «Спорт у житті людини», «День народження», «Український патріот», «Пори року в Україні», «Хай буде мир на землі», «У поліклініці».

Загальний навчальний час, відведений на опанування соціокультурного матеріалу, складає неповних $17 \%$. У свою чергу, запропонований матеріал характеризується неповнотою культурного насичення: у тематичному змісті відсутня деталізація інформації про сферу повсякденного життя (не розкрито особливості етикету за столом, комунікативної / некомунікативної поведінки в межах статевих / сімейних / колективних / суспільно-виробничих / громадських відносин / міжнаціональних на території України; не подано характерних рис національної невербальної комунікативної поведінки; не наявні також відомості про традиції, звичаї, обряди українського народу, відсутні дані про поведінкову реакцію носіїв мови на неадекватне вживання тієї чи тієї мовної форми або помилково використаної невербальної форми комунікації [4].

Отже, аналіз навчальної літератури показав, що нині більшість програм, підручників і посібників із української мови як іноземної містить велику кількість мовного і мовленнєвого матеріалу, яким іноземні студенти мають оволодіти на початковому етапі навчання задля послуговування усним і писемним мовленням у побутовій та освітній сферах діяльності. Водночас соціокультурній царині приділено недостатньо уваги: більшість текстів містить країнознавчі відомості про історію, географію, духовну культуру (біографія історичних постатей, відомих спортсменів, видатних письменників і поетів) та матеріальну (культурні пам'ятки, музичні інструменти, твори художнього, літературного і музичного мистецтва), проте лінгвокраїнознавчий аспект розкрито не повністю: стисло розглянуто слова-реалії, що присутні в одній та відсутні в іншій культурі чи не збігаються в обох культурах. На наш погляд, звернення до національно-культурної маркованої лексики надає змогу ознайомити адресата з додатковою інформацією культурологічного характеру, яку закодовано в мові та яка є нетотожною в різних мовах (традиції, звичаї, обряди, норми повсякденної поведінки, невербальні засоби спілкування) задля того, щоб запобігти вживанню мовних засобів і поведінки, які не відповідають тій чи тій комунікативній ситуації.

\section{Література}

1. Борисова 3. У. Навчальна дисципліни «Українська мова» (довузівська підготовка) / 
3. У. Борисова. - Київ : МАУП, 2008. - 24 с. 2. Навчальні плани та програми (довузівська підготовка іноземних громадян) / уклад. : Л. Г. Новицька, О. Ф. Гудзенко, М. І. Дудка та ін. Київ : ІВЦ Видавництво «Політехніка», 2003. - Ч. 1 (Українська мова, Основи економіки, Біологія ...). - 56 с. 3. Програма з української мови для студентів-іноземців підготовчих факультетів України // укладач: Л. Г. Новицька. - Київ : Міністерство освіти і науки України (21 лютого 2002 р., протокол № 4). - 25 с. 4. Програма навчальної дисципліни та робоча програма навчальної дисципліни «Українська (російська мова) мова» (для студентівіноземців підготовчого відділення за спеціальністю гуманітарні) / укладач: Л. В. Сергійчук / за ред. Ю. Ю. Конюшенко. - Харків : ХНАМГ. - 2012. - 18 с. 5. Ушакова Н. І. Концепція мовної підготовки іноземців у ВН3 України / Н. І. Ушакова, В. В. Дубичинський, О. М. Тростинська // Викладання мов у вищих навчальних закладах освіти. Міжпредметні зв'язки : [зб. наук. праць]. - Харків : ХНУ ім. В. Н. Каразіна, 2011. - Вип. 19. - С. 136-146.

УДК 372.8:371.2

Неля Подлевська

\section{КОМП'ЮТЕРНО ОРІСНТОВАНІ ПЕДАГОГІЧНІ ЗАСОБИ В ЗАБЕЗПЕЧЕННІ НАВЧАЛЬНОГО ПРОЦЕСУ СТАРШОКЛАСНИКІВ}

Подлевська Н. В. Комп’ютерно орієнтовані педагогічні засоби в забезпеченні навчального процесу старшокласників.

У статті приділяється увага значенню використання мультимедійних засобів навчання, їх можливостей у навчанні старшокласників на профільному рівні для оптимізації навчання, зокрема, філологічного; розкривається роль комп'ютерно орієнтованого навчання як сучасного засобу інформаційно-комунікативних технологій в освіті.

Ключові слова: комп’ютерно орієнтовані засоби навчання, мультимедійні засоби, інформаційно-комунікативні технології, профільне (філологічне) навчання старшокласників.

Подлевская Н. В. Компьютерно ориентированные педагогические средства в обеспечении учебного процесса старшеклассников.

В статье уделяется внимание значению использования мультимедийных средств обучения, их возможностей в обучении старшеклассников на профильном уровне для оптимизации обучения, в частности, филологического; раскрывается роль компьютерно ориентированного обучения как современного средства информационно-коммуникативных технологий в образовании.

Ключевые слова: компьютерно ориентированные средства обучения, мультимедийные средства, информационно-коммуникативные технологии, профильное (филологическое) обучение старшеклассников.

Podlevska N. V. Computer-oriented pedagogical tools in educational process of senior high school students.

The article deals with the importance of using multimedia training tools as well as their potential in teaching senior high school students at a subject oriented level, philological in particular. The role of computer-based learning as a modern mean of information and communication technology in education was revealed.

Key words: computer-oriented training, multimedia training tools, information and communication technologies, subject oriented instruction (philological) of senior high school 